DOI 10.5937/kultura2069249V

UDK 338.46:005.745

316.7:005.745

originalan naučni rad

\title{
CREATIVECLUSTERS
}

\section{TYPOLOGY, CHARACTERISTICS, FINANCIAL MODELS AND SUCCESS FACTORS}

\begin{abstract}
The global pandemic is changing the world in significantly high speed and in many dimensions-economic, social, cultural, digital. Covid-19 certainly had a negative effect on all sectors requiring traveling and physical presence, including many arts and culture events and organisations, as well as sectors that are complementary to the culture and creative industries value chain. Despite, the global pandemic opened up new opportunities of living more among our communities, consuming more local products, reorganising our life to be more resilient, catalyzing both business and social innovations, using much more digital and online tools, including also for further increase of cultural participation and democratisation of the arts. In the last few months we have received plenty of evidences worldwide that culture does contribute to the economic and social vitality of cities across the world. This paper aims to identify the essence and key characteristics of "creative clusters" (CCs) and to offer a typology of their diverse forms of existence. It also summarises key business models and sources of external financial support for development of CCs. Finally, the paper draws key success factors for their development. The research for elaboration of this paper was done during 3-months long period (AprilJune 2020) in collaboration with Nikoloz Nadirashvili and Creative Georgia, within the framework of the Project - "Designing a Creative Cluster Ecosystem in Georgia" under the support of UNESCO and the European Commission. The research methods used for elaboration of this paper are: desk research of documents and publications, mapping and analysis of diverse cases and targeted in-depth interviews with professionals and managers running creative clusters.
\end{abstract}

Key words: creative clusters, creative hubs, creative districts, cultureled urban regeneration 


\section{Creative Clusters as Catalysts for Development of Creative Cities ${ }^{1}$}

Culture is now recognised by many cities worldwide as a key resource for urban development and regeneration. The concept of a "Creative City", evolving since late 1980s, is an important and inspiring trend in the local cultural planning for many cities worldwide. The focus of the creative city is on the creativity and talent of people at the local level as a potential to boost the economy, transform the image of the city, unlock the creative potential, combine resources in a creative way and attract international investments. Many cities worldwide undertake a mapping of their cultural resources (tangible and intangible one) for the purpose of involving them in the city cultural planning in an integrated way-in connection with city's other development plans - infrastructure, tourism, health care, education, environment, etc. The importance of the "creative city" concept today, among other angles, is that it advocates for putting culture and creativity on the priority agenda in the urban planning and strategies, contributing to the development of the concept of "shared policies". Creative City" is not only about boosting the economic development through creativity, but also, emphasizing on burning social issues at local level, such as: cultural diversity, social cohesion, creating livable conditions for the citizens, respecting human and cultural rights.

Creative clusters (CCs) stay as a key concept in the theoretical resources and practices of developing of creative cities. Initially, "business cluster" as a concept was introduced by Michael Porter, emphasising on the geographical, sectoral or horizontal connections between companies that aim at increasing their joint potential to face a competitive environment ${ }^{2}$. There is no common definition of what "creative cluster" stands for. The scope and characteristics of each cluster depend on the local context, which is usually very unique and specific for every city or region. Most often, CCs are meant to have an emphasis on the geographical concentration of different organisations that combine in a compatible way their assets in order to seek and use local resources. The research shows that the diverse theoretical resources (see Appendix 1) define CCs as:

1 This paper is elaborated within the framework of the Project - "Designing a Creative Cluster Ecosystem in Georgia" under the support of UNESCO and the European Commission. Special thanks to Nikoloz Nadirashvili and Creative Georgia (creatvegeorgia.ge) team for assisting the research (April-June 2020) and to all interviewees - experts and managers of creative clusters, listed in Appendix 2.

2 Porter, M. (1990) The Competitive Advantage of Nations, New York: Free Press. 
- communities of creative individuals who share common goals and resources, have a sense of belonging and are connected around creativity;

- group of companies of similar or different type, with geographic proximity who establish relationships in order to spark an innovation in the sector of culture and creative industries;

- part of a neighbourhood or a district in a city with a special creative spirit and infrastructure that motivates tourists and citizens to use creative places and spaces;

- mutually dependent entities in CCIs and beyond who share communalities and competences to undertake a joined project that use local resources.

The term "cluster' is used also as a virtual or online network that is connected via Internet or another digital mean. Organisations that are included in a creative cluster can be different in their legal and governance structure-entrepreneurial startups, businesses, educational institutions, arts and cultural organisations, venues, service providers, financial institutions, research organisations, as well as individual artists, creatives and experts. In most of the cases these organisations are related to different phases of the value chain process-from production to dissemination and monetization of creative products and services.

\section{Key Characteristics of Creative Clusters}

Creative clusters are proven cultural policy tool for transformation in many cities and regions of the world. They are an instrument for creative city development and implementation of culture-led regeneration strategies. As part of development of culture and creative industries, CCs are a way for creative businesses and companies to implement an effective strategy that is based on their competitiveness and market advantage. $\mathrm{CCs}$ also have a societal angle - the impact on the society and communities is an immense part of their activities and goals, connecting heritage and contemporary arts with numerous social activities, such as events and festivals. It is important to also emphasise that CCs impact communities and local development. They offer public goods and services, shared spaces and resources.

Even if different in forms, locations and other parameters, the current research identifies that creative clusters have several common characteristics:

- Shared location, resources, facilities, assets. CCs combine organisations and individuals on a mutual sharing principle. 
- Creativity and innovation. They stay in the focus of every $\mathrm{CC}$ and determine the programming policy and activities offered.

- Complexity. Most CCs are complex in their nature and programming. They also differ in terms of the level of complexity, which is usually rather high (see below).

- Autonomy. CCs need to keep independence and autonomy in its programming and initiatives in order to work effectively. This is why many of them develop a mixed financial portfolio of external and internal sources, without being dependent on a single funding source.

- Common mission and goals. Organisations, included in a $\mathrm{CC}$, have common mission, goals and values that in most cases are related to both economic and social development.

- Regional proximity / locality. CCs are regional, or local, existing in a specific geographic area.

- Skilled creative labour. CCs rely on creative individuals who are the key resource with their ongoing creativity, vivid interactions and collaborative pattern of behaviour.

- Crossover innovation capacity and multidisciplinary angle. One of the key objectives for forming a $\mathrm{CC}$ is to sparkle innovation, both business and social one, especially innovations between sectors.

- Social entrepreneurship. CCs are catalyst for startups in a city/region, especially the ones that have social aspects and not-for-profit goals, not only economic goals and commercial business models.

- Synergy. CCsbring together organisations and individuals who combine resources and competences in a way that leads to a higher end result than if working individually.

Creative clusters differ based on the following variables (see examples below):

- Years of existence: As a relatively new phenomena, the "oldest" CCs exist for already 30 years, while others are very new and are set up recently. There are also CCs that have been formed for only a few years, mainly based on external funding from government, corporations, foundations and individuals, and after completing the project, the $\mathrm{CC}$ has been dissolved. Some CCs are very advanced and constantly develop during the years, 
diversifying their strategies, while others stay small and do not grow.

- Initiator. CCs can be initiated by diverse organisations and individuals. In some cases a city council decides to form a creative clusters, considering economic and social policy objectives. In other cases, a group of creatives from one or different CCIs branches is the sparkle for formation of a CC. There are situations in which a $\mathrm{CC}$ is formed as a consortium between partners in order to attract specific external financing. A university, research organisation, IT company, cultural organisation of any type (non-profit, business or public) could also be an initiator of a $\mathrm{CC}$, inspiring others to join. Some $\mathrm{CCs}$ are formed based on grassroots initiatives, coming from activists, or leaders of non-profit organisations whose mission is to connect arts with community, organise street festivals and other free public events.

- Purpose. This variable is one of the broadest, because the mission and key objectives of the $\mathrm{CCs}$ are very different - individual support of cultural entrepreneurs, organisational capacity building, promotion of culture and creative industries on regional level, or other policyrelated objectives.

Level: A CC can be formed at:

- Organisational level (e.g. co-working spaces, shared premises, etc.

- Level of neighbourhood or district (e.g. creative district).

- City level (in cases where the whole city is branded as "creative city" based on many creative clusters.

- Types of organisations. CCs are heterogeneous - they consists of different types of organisations - e.g. businesses, research organisations, educational entities, nonprofits, public organisations, etc. Organisational structures are also different-varying from very fluid and open, to quite agile and accepting only members who pay a fee.

- Scope. Some CCs function in more than one branch of CCIs (heterogeneous), while others are specialized in one branch (homogeneous), e.g. textile cluster, film cluster, theatre cluster, etc. Homogeneous clusters usually combine companies that have different positioning in the value chain-e.g. a production company, marketing company and a supply chain company. There are creative 
clusters that connect CCIs with other areas, such as business and innovation (e.g. creative incubators and accelerators).

- Involvement of new technologies. CCs can be a combination between culture, arts and digital technologies, or organising only around technological activities (tech clusters). Some tech clusters could be related to augmented or virtual reality and their implementation in the artistic fields.

- Management and governance. CCs differ based on the way they are formed-some of them are informal structures (e.g. creative hubs, communities of artists and creatives), while others are formal structures and are part of the city policy strategic development (e.g. creative districts, mega-projects, creative suburbs). Some CCs are established legally as organisations in accordance to the country's legislation (e.g. social businesses, nonprofits, associations, or creative enterprises). The level of cooperation and partnership between members is different in these diverse settings.

- Business models. CCs have diverse external funding and internal sources of revenues. Their incomes could be based on membership, paying fees for services, external financing, ongoing fundraising from different sources, and so on.

- Time: Some CCs are formed for temporary period of time in order to undertake a project, while others are long term strategic alliances between organisations involved.

\section{Typology of Creative Clusters}

As mentioned above, creative clusters differ based on many variables, while at the same time having common characteristics. Figure 1 provides an overview of the types of CCs that are most common in the practice. They are separated in the figure for better understanding of the typology, although cultural and artistic practices show that their activities overlap - one $\mathrm{CC}$ could be part of another one. For example, creative hubs, incubators and accelerators could be part of creative suburbs and neighbourhoods. A cc in one branch of CCIs could also include an accelerator for creative ideas, or an arts collective could be a $\mathrm{CC}$ that covers two and more CCIs branches.

\section{Creative neighbourhoods and suburbs}

Culture-led urban regeneration strategies in many post-industrial cities around the world have transformed abandoned places into 
cultural, artistic and social venues. These buildings - former military bases, old factories, flour-mils, old ships, local train stations, ruined industrial sites - have been isolated before from the rest of the city life and have generated a lot of economic and social problems. Creative neighbourhoods and suburbs are the result of culture-led urban regeneration.

The initiative for transformation of post-industrial abandoned buildings come from the local communities, artistic cooperatives, young people, networks, the civil society sector, or the local/ national government. The key goals of establishment of a creative neighbourhoods and suburbs are:

- to preserve a historical site that is part of the collective memory of the city or the region;

- to improve the image of an isolated part of the city by transforming it into an area with good reputation for culture, leisure and entertainment;

- to attract visitors and residents in isolated areas and to serve them better by offering diverse "menu" of cultural and artistic programming;

- to improve the quality of life of the inhabitants by incorporating a quality urban design an architecture, and investing in public arts;

- to decrease unemployment, social exclusion, poverty and other social problems;

- to foster intercultural dialogue and create a peaceful local environment between diverse ethnic and minority groups of the population;

- to give a voice to artists, especially young and emerging artists, to experiment, create and network;

- to connect artistic/creative experiences with educational programs at all levels within a local context.

Establishment of such creative neighbourhoods and suburbs require a combination of influencing factors at local level, such as: public commitment and leadership, high level of engagement of the civil society players, initiation of a public dialogue and consultation with inhabitants of the respective region, collaboration between diverse actors such as urbanists, policymakers, artists, architects, businesses and investors.

The newly established venues in the creative neighbourhood are usually multi-functional, combining diverse artistic and educational activities. Some of them offer mainly entertainment programs, while others stress on contemporary arts offerings. 
In most cases, the new spaces offer indoor and outdoor spaces for multiple purposes: rehearsal studios, cinema halls, theater and dance stages, rooms for workshops, classes and lectures, spaces for debates and round tables, restaurants and bars, open green areas for relaxation and leisure activities. Many of them encourage emerging artists and offer debut stages, increasing the access of young people to culture.

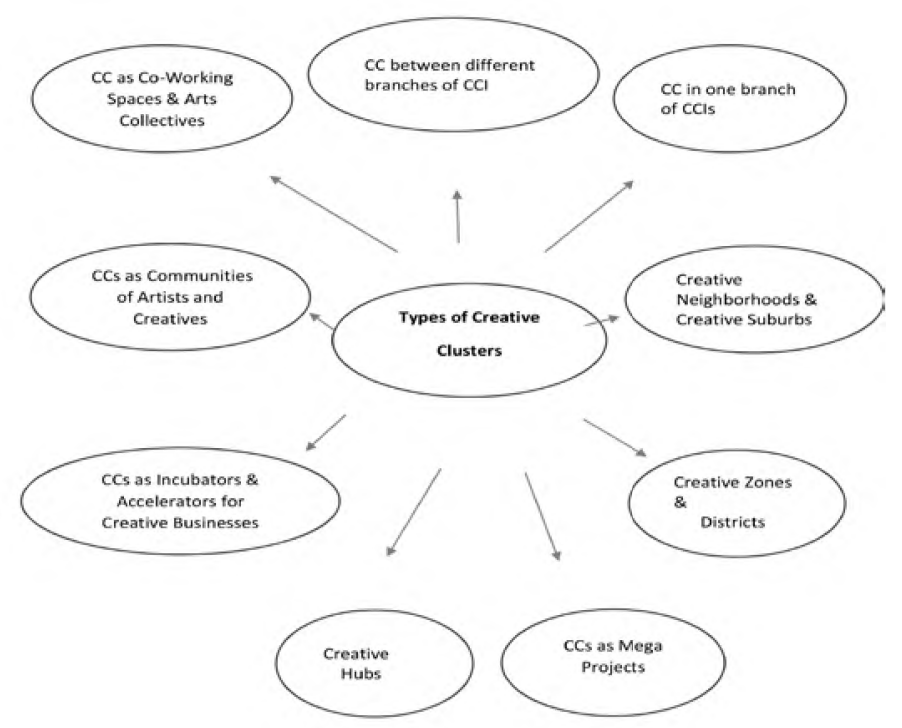

Fig 1: Types of creative districts

Creative zones and districts

Creative districts play an important role in development of creative industries and creative economy in a city. They are a catalyst for the local economic development that is based on creative entrepreneurship. Creative zones and districts are attraction for foreign and domestic investments, especially when developed in connection with industries with high potential for growth, such as IT sector, biotechnologies, renewable energy sources, robotics, augmented and virtual reality and others. They are also important for job creation and development of new working areas for creatives. Creative districts are also a booster for tourism in a city, and a motivator for people to live there.

There are also some negative aspects from the development of creative zones and districts, for example when a marginalized neighborhood is transformed into a luxury place, it becomes quite expensive for communities to live there. 


\section{Creative hubs}

"Creative hub" is a term that has many connotations, although in most of the cases it relates to physical or virtual places that bring likeminded people together, mainly working in the field of arts and creative industries (but not limited to that). The European Creative Hubs Network provides the following definition: "Creative hub is a physical space for creative \& cultural professionals that offers the most effective way to support their growth, collaboration, interaction and development"3. Some creative hubs are specialized in a specific branch of arts of creative industries (e.g. theatre hub, design hub, crafts hub), others bring professionals from many different areas. Hubs have a fluid form and open democratic structure-everyone can join or leave at any time. There is no membership fee or another form of participation on a paid basis. The form of a creative hub depends on several variables, among them: its purpose and reason of existence, the context of the city where it operates and the community settings (if offline). The initiators and organisers of the hub - "hub managers" or leaders, play a crucial role in the hub's operations, as in many cases their energy and enthusiasm keep this form of creative cluster alive. They are also "connectors" between the creatives and the local communities. Creative hubs contribute indirectly to the growth of the local creative economy, as they are the place where a sparking innovative idea could be created and later on-commercialized in an effective business model.

\section{Incubators and Accelerators for Creative Businesses}

In the practice of creative entrepreneurship, the terms "accelerator" and "incubator" are often used as similar concepts, however they have differences in their key purpose, operational and financial structure and other variables. Incubators and accelerators for creative ideas are considered as a type of creative cluster, because they fit to some of the characteristics of a cluster, provided above. Both "clusters" provide mentoring, training, technical assistance, and in some cases seed money for startup creative entrepreneurs. Table 1 provides an overview of the differences between the two.

\section{Co-working spaces}

Co-working spaces for creatives and artists offer shared resources - spaces, services, equipment and others. They can bring artists from one and the same industry branch (e.g. designers, film-makers, software specialists, musicians, etc.)

3 Source: European Creative Hubs Network FAQ: http://creativehubs.net/faq/ 


\section{LIDIA VARBANOVA}

to get together and learn from one another. Co-working spaces can target only female artists, or young entrepreneurs, or they can provide access for everyone in the creative businesses. The benefits of co-working spaces, among many, are the following:

- Cost efficiency: decreasing the overhead costs in the structure of creative businesses.

- Equipment and space that is more suitable than the individual one.

- Networking environment where artists and creatives can get inspired and innovate because of the shared mode.

- There are numerous co-working spaces around the world with plenty of concepts for their offered shared services ${ }^{4}$.

\begin{tabular}{|c|c|c|}
\hline Variables & Inculoator & Accelerator \\
\hline Purpose & $\begin{array}{l}\text { Helps a creative entrepreneur to } \\
\text { build a business from ground up. } \\
\text { "Incubate" an idea with the } \\
\text { direction of building a business } \\
\text { model around it, and later on-a } \\
\text { company. }\end{array}$ & $\begin{array}{l}\text { Helps a creative startup to reach a next } \\
\text { level in the business development. } \\
\text { Accelerate growth of an existing } \\
\text { startup. }\end{array}$ \\
\hline Focus & Innovation (social or business) & Scaling a creative business \\
\hline $\begin{array}{l}\text { Application } \\
\text { process }\end{array}$ & $\begin{array}{l}\text { Select participants that have } \\
\text { disruptive ideas, in some cases } \\
\text { based also on references. }\end{array}$ & Rigid selection, highly competitive \\
\hline $\begin{array}{l}\text { Programs and } \\
\text { Services } \\
\text { offered }\end{array}$ & $\begin{array}{l}\text { Open-ended format: } \\
\text { In some cases offers co-shared } \\
\text { space for work. }\end{array}$ & $\begin{array}{l}\text { Planned activities that need to be } \\
\text { followed (training, mentoring, } \\
\text { networking, etc.) }\end{array}$ \\
\hline $\begin{array}{l}\text { Financial } \\
\text { structure }\end{array}$ & $\begin{array}{l}\text { Typically a non-profit entity } \\
\text { relying on outside funding. Some } \\
\text { inculoators are part of a university } \\
\text { or another structure. Do not take } \\
\text { commission from the participating } \\
\text { entrepreneurs. Do not provide up } \\
\text { front financing and does not } \\
\text { expect equity in retum. }\end{array}$ & $\begin{array}{l}\text { Typically for profit entity, in most } \\
\text { cases privately run, accepting equity } \\
\text { from participants' startups for using the } \\
\text { services and having mentorship. In } \\
\text { some cases provide seed investment. }\end{array}$ \\
\hline Timing & $\begin{array}{l}\text { No fixed time; mentorship can } \\
\text { extend up to } 2 \text { years, depending on } \\
\text { the needs of participants. }\end{array}$ & Short time (usually 1-4 months) \\
\hline
\end{tabular}

Table 1: Differences between "incubator" and "accelerator" for creative startups

4 See: 11 Inspirational Co-working Spaces: https:/www.creativebloq. com/inspiration/11-inspirational-co-working-spaces-to-make-you-morecreative and: Co-working Spaces for Artists and Creatives: https://www coworkingresources.org $/ \mathrm{b} \log /$ coworking-spaces-for-artists-and-creatives 


\section{Creative Clusters in the Digital Realm}

Creative clusters worldwide use digital technologies and online tools in five main ways:

- Producing cultural/creative content in a digital format. This is in cases when a product/service does not exist offline, but only online. Development of entirely virtual programming is a trend in the arts, culture and creative industries field. The new media art, digital art, use of virtual reality forms are some of the ways by which this is happening.

- Selling cultural/creative products and services. Such ways include: lifestreaming, podcasts, online shops for selling paintings and other art objects, pdf and kindle editions of books, download of music and films on a paid basis, offering merchandising online, and others.

- Digital marketing. This includes all online and digital ways for dissemination, communication and promotion of cultural/creative products and services through variety of tools, such as: websites, blogs, social networks, online portfolio, online branding, PR online, hashtags, mobile devices, search engine optimisation and others.

- Fundraising and financing. Digital realm offer innovative way by which cultural/creative products and services of CCs could attract external support via diverse methods, such as: crowdfinancing, crowdfunding, donations online. It also offers ways for online business models, such as websites affiliation, advertising models, fermium models and many others.

Creative clusters could also exist entirely online, although in these cases they are called "virtual creative clusters" (VCCs). The dynamics and the rules based on which they exist, are different from the physical presence of CCs. In many cases these VCCs are called online networks, or virtual communities, because as mentioned above, the term "cluster" implies spatial co-location of the organisations included in the cluster. Digital creative clusters are found also in some of the sub-sectors of CCIs where new technologies are predominant, such as: software, IT, computer games, advertising and others.

The research highlights five key challenges and barriers in development of creative clusters in the digital realm, as follows:

- Digital competences. Many CCs face issue with insufficient or irrelevant skills and competences of creatives (e.g. artists, clusters' teams and managers) to 
work online and to properly use the new technologies. Also, time allocation to elaborate and implement digital strategy is not possible because of limited number of people involved in management of the $\mathrm{CC}$.

- Access to public funding. In many countries, government support is not directed towards digitalisation in arts, culture and creative industries, incl. creative clusters online.

- Shared resources. Digital CCs require also a physical presence and shared resources to decrease their overhead costs. Such resources are not always easy to access locally.

- Lack of corporate support. Businesses in many countries prefer to invest in the "evening economy" and "leisure industries" when there is an urban transformation, rather than in creative and digital spaces.

- Insufficient collaboration. Online technologies offer opportunities for collaboration, although from practical perspective CC teams and managers do not use digitalisation as a mean to collaborate and set up effective business models as a result.

\section{Examples of creative clusters}

\section{Creative Cardiffli}

\section{History and objectives}

Creative Cardiff is a network, which connects people working in any creative organisation, business or job in the Cardiff region. The mission of the organisation is that "by encouraging people to work together we believe that we can make Cardiff the most creative place it can be". The key aim is to bring together people from across the full breadth of the city's creative economyfrom dancers and marketing professionals to architects and app developers in order to encourage more innovation and creativity in Cardiff as a creative city.

Since its inception in 2015, Creative Cardiff has built a community of over 3500 creative organisations and freelancers across the Cardiff City Region. Through a range of initiatives, it is now widely recognised - in South Wales and beyond - as a catalyst (and a model) for creative collaboration. 


\section{Programs and services}

The network connects the creative economy across the Cardiff region, promoting and enabling collaboration for economic, cultural and social benefit. Creative Cardiff's activity is focused around three main strands of work; fostering Connections \& Collaborations, encouraging Enterprise \& Entrepreneurship, and Telling Cardiff's creative story.

Creative Cardiff offers online and offline ways of engaging through a range of digital communications, events, research and projects which include:

- An online network directory

- Jobs \& Opportunities website page including listing $4000+$ jobs over the past 4 years

- Mapping research to assess and visualise the cluster, it's assets and workforce

- English and Welsh language podcasts

- Sub-network meet-ups e.g. Immersive South Wales, Coworking collective

- Q\&A events with leaders of the creative sectors

- Website resource pages e.g. funding + grant opportunities, information in a time of covid-19

- $200+$ news and feature articles

- Community engagement projects e.g. Community Gateway

\section{Target groups}

A wide network that includes individuals, freelancers, micros, small and medium sized businesses and stakeholders.

\section{Organisational and financial matters}

Creative Cardiff is supported by Cardiff University. Founding partners are: Wales Millennium Centre, BBC Cymru Wales and Cardiff City Council.

\section{Strategic directions and future plans}

In 2018, Creative Cardiff built and led a partnership - including 3 Universities, City and Welsh Government, a range of strategic organisations and over 40 creative companies - for a successful bid to become one of nine AHRC/Industrial Strategy Creative Clusters in the UK. This brings investment of $£ 9 \mathrm{~m}$ into the 
region and will allow Creative Cardiff to significantly extend its research and development activity.

Creative Cardiff will be undertaking work to connect and engage the leaders of other UK and worldwide creative industries cluster networks in 2020 to achieve a better understanding of these entities and explore potential of future research and engagement collaborations.

The network will also look to develop its understanding of the wider city region as well as its offering for freelancers with a particular focus on enterprise and entrepreneurship.

\section{CRU Cowork, Porto, Portugal 5}

\section{History and objectives}

CRU is one of Porto's first collaborative places - a creative hub, located at Bombardia-Porto Art District. It was created in 2012. CRU is a place to attract talented, motivated and creative people to form a vibrant and diverse community and a shared place for them to work, to exhibit and to sell their creative products. The space has a coworking area, a gallery and a store.

CRU functions as a platform for launching independent projects, brands and authors while at the same time having a social mission to raise awareness about artistic creation.

\section{Operational and financial matters}

CRU has around 40 creative people working at the space on a daily basis, and 50 brands represented in the store. The network consists of over 250 people: designers and entrepreneurs whose brands are represented in CRU store, and also partners, experts and trainers. Those artpreneurs and freelancers represent a wide range of CCIs,. Such as : design, architecture, photography, illustration, stage direction, journalism, translation, marketing, software development and social sciences.

CRU team is a combination of people with diverse competences and transdisciplinary profiles - from psychology, music, informatics, plastic arts, economics and photography.

CRU is legally registered as both non-profit organisation and a trade company to be able to run both projects with social goals, and raise money from self-generated activities, such as: membership fees, services offered, organisation of events and conferences, and others.

5 CRU Creative Hub Website: https://cru-cowork.com/en 
Impact HUB, Prague, Czech Republic ${ }^{6}$

\section{History and goals}

The HUB is the Czech part of "THE HUB network", established in 2005 in London. It was founded in 2010 and in 2016 its members exceeded 600. The HUB currently operates in three cities: Prague (two hubs), Bruno and Ostrawa as an inspirational co-working space, helping startups to accelerate, network and advance.

The mission of the HUB is to support the development of startups, companies and nonprofits, taking the role of a mentor that points out the right direction, giving an expert response to every question and valuable contacts that can make everything easier ${ }^{7}$. The HUB concentrates on social innovation, making an impact, and also allows people from diverse areas to participate and network in order to catalyze creative ideas that lead to successful implementation of creative ideas.

\section{Programs offered}

- Impact first - directed towards nonprofits and social businesses

- Climate change - assisting projects addressing environmental issues

- Ideation - two months program for early stage entrepreneurs with ideas

- Social impact award - targeting young social business innovators

- Start it $@$ CSOB - program for existing teams that have innovative idea

The HUB also offers spaces for rent, such as: conference hall, dance floor, meeting room, garden for unique events. It has hosted hundreds of events and cooperated with large companies as well as individuals.

\section{Organisational and financial matters}

The HUB is registered as a limited company, playing the role of a social enterprise. Most of its financing comes from its members and tenants/renters - around $75 \%$ are self-generated revenues, another $25 \%$ come from external sources-e.g. corporate support and public funding, mainly European funds. Corporations support the HUB from their marketing of CSR

6 Prague HUB website: https://www.hubpraha.cz/en

7 Source: https://www.hubpraha.cz/en/acceleration/ 
budgets, enriching the value for their business by connecting with the communities and creative people.

The hub has 65 people full time (before coronavirus breakout they were 125), and over 200 mentors and experts.

\section{MTNS MADE Creative Industries Cluster, Australia ${ }^{8}$}

\section{History and goals}

This Cluster aims to grow and strengthen the creative industries in the Blue Mountains, by facilitating collaboration, exploring new market opportunities, providing access to training and networking and marketing the region as a world-class creative hub. The Cluster is created in 2015 as a collaborative initiative

\section{Services offered}

Among the key services which the Cluster offers, are the following:

- Monthly Salon for sharing stories, ideas and connections

- Annual creative industries symposium

- Creative match-making of members for collaborative projects

- Brokering contracts and agreements between creatives and commercial opportunities

- Shared co-working space

- Positioning MTNS MADE as a brand to promote the region as a world-class creative hub.

- Representing Blue Mountains creatives at art fairs across the state, and contributing events to significant festivals such as Vivid Ideas Sydney.

\section{Operational matters}

The Cluster is an initiative of Blue Mountains Economic Enterprise (BMEE) ${ }^{9}$, the peak economic development agency for Blue Mountains, whose mission is to stimulate economic development through advocacy, investment and industry development. BMEE receives operational funding from Blue Mountains City Council. The cluster does not have formal

8 Website: https://mtnsmade.com.au/; See also: https://www.

clustercollaboration.eu/cluster-organisations/mtns-made-creative-industriescluster

9 Website: https://bmee.org.au 
membership, but it serves a community of around 2,700 creative professionals living and working in the region. Across the creative professions are several creative industries branches, such as: design, visual arts, film, sound and music, publishing and performing arts. Over 500 creative professionals are already listed on the MTNS MADE directory where users can read their stories, view their portfolios and contact them directly. Some of the creative are born in the region, others are refugees and people coming from diverse marginal groups. Creative practitioners from all over the world come here to live, to work, and to connect with our thriving creative community.

\section{Sectie-C, Eindhoven, The Netherlands ${ }^{10}$}

\section{History and objectives}

Sectie- $\mathrm{C}$ opened doors 10 years ago as a unique and vibrant space for designers, authentic doers and independent thinkers who seek possibilities instead of looking at limitations. They made shared workshops, co-working spaces, studios, garden premises, labs and more. The famous Dutch Design Week also takes place here every October and attracts yearly around 25.000 visitors to the exhibitions, open studios and events.

Sectie- $\mathrm{C}$ team believes in the connection between creatives and community, the feeling of being a "family" and having an open democratic structure that supports experimentation, mutual learning and collaborations. Sectic-C is an organic collaboration platform of more than 250 creative entrepreneurs, artists, photographers, designers, musicians, communicators, and craftmakers. Many of inhabitants of the space are well known beyond borders while at the same time contributing to transforming Eindhoven into a creative city.

\section{Operational and financial matters}

Sectie- $\mathrm{C}$ is a non-profit organisation consisting of a foundation with an association of renters who contribute to the association in order to be represented at the owner of the buildings. The foundation creates a vision to grow and develop the identity of the space and to secure a legal structure and future financial sustainability.

\section{Financial Models for Development of Creative Clusters}

Financial sustainability is one of the key issues in keeping creative clusters active in a long period of time.. Below is the summary of the business models for CCs establishment and running.

10 Sectie-C website: https://www.sectie-c.com/ 
- State-subsidized. The first option is establishing a CC with public money, coming from a local authority (municipality, city council etc.), government agency (one or several ministries), or European funding. This approach could be stable only if the decision-making authority has secured a long-term budget for the $\mathrm{CC}$ development. In many countries due to changes in political power, this option seems to be not that stable. In some cases, the ownership is kept public, while the CC is run by a non-profit organisation. Such a governance structure is a bottom-up approach, which has proven a better sustainability.

- Self-financed. The second option is when a CC builds up its business model, based primarily on self-financing and self-generated revenues from variety of sources, such as: membership, offering paid services (workshops, information, mentoring, coaching, etc.) and rent of spaces for creatives and artists. In this case, the rent is lower than the one offered on the market, and this is an important benefit for the artists, although it is hard to negotiate with the property owners lower prices for rent. Another benefit in renting co-space and places for creativity is the flexibility-an artist can rent it for a few months, and not for a whole year.

- Diverse sources of financing and revenues. The third option is a balanced combination between external funding sources and self-generated revenues. Sources of external financing differ - they could be: pubic money, foundations (local, national, international), European commission programs, or universities. Examples include, among many: FutureLab in Eindhoven ${ }^{11}$, having $60 \%$ public funding and $40 \%$ self-generated revenues, and Creativehubs network ${ }^{12}$ which made a transition from European funding to self-sustainable model. Belgium government provides funding for innovation projects, but requires partnership between university, researchers and creators.

- Corporate support

- The fourth option is based on private investment schemes as a way to elaborate a business model. Such investments come from corporations, or individuals, in diverse forms - e.g. coalition of business companies, an investors,

11 FutureLab website: https:/futurelab-eindhoven.n1/

12 Creativehubs network website: http://creativehubs.net/ 
having an equity in the future business. Corporate support could come from commercial companies, banks, insurance companies, real estate companies, or construction companies - in cases when $\mathrm{CC}$ is connected with renovation of a building (an example is Volkstrant Building in Amsterdam ${ }^{13}$ ). In the cases of business accelerators for creative ideas that act as commercial entities, creative entrepreneurs pay a fee to the accelerator for joining, and private individuals (angel investors and others) hold an equity in the future growth of the startups.

- Crowdfunding and crowdfinancing ${ }^{14}$ are becoming popular methods worldwide for support of creative industry projects, including also projects of creative clusters. Examples of some of the well-known and widely used on national level platforms are the following:

1. BigIdea ${ }^{15}$, Ukraine: Allowing collection of funds for ideas supporting systematic change and open society in diverse fields such as: literature, music, research, education, health care and research.

2. CrowdCulture ${ }^{16}$, Sweden: Project creators can attract funding from private investors, as well as from state funds.

3. Goteo ${ }^{17}$, Spain: A successful platform for starting and implementing projects with social impact. Apart from monetary contributions, it is possible to collaborate through services, material resources, infrastructure or by participating in specific micro tasks needed for the development of projects. Goteo also has a unique financing methodology carried out in two rounds lasting 40 days each.

4. Ulule ${ }^{18}$, France: founded in 2010 as the first platform that can collect funding also offering a pre-sale of the product/service.

13 Source: Volkstrand Building Research: https://www.volkshotel.nl/en/blog/ art-cult/volkskrant-building-research/

14 Note: Crowdfunding is based on donations, while crowdfinancing is an investment by individuals who have a stake/share in the future company. The first one is philanthropic-based, the second one -investment based.

15 Bigledea website: https://biggggidea.com/projects/

16 CrowdCulture website: https://crowdculture.se/en

17 Goteo website: http://en.goteo.org/

18 Ulule website: https://www.ulule.com/ 
5. Wemakeit ${ }^{19}$, Switzerland: The largest Swiss platform for creative industries, supporting people to sell design products, develop apps, publish coopery books, support startup companies, as well as non-profit organisations to develop their communities.

6. Ulej ${ }^{20}$ and Talaka ${ }^{21}$, Belarus: the first crowdfunding platforms in the country, allowing collecting funds for good purposes.

There are also innovative business models for support of CCs, based on collective ownership, buildings where the ownership belongs to a "social housing agency", accumulating profits to reinvest in the property development.

\section{Success Factors}

Experts and $\mathrm{CC}$ managers, involved in this research, share several key factors that determine the success of starting and developing a creative cluster, as follows:

- Observe what is already existing in the specific place and built up on organisation, initiative or coalition that already exist in the city/region.

- Mind the uniqueness and the resources of the place, understand the context in which the CC operates.

- Set up a partnership framework. Take your time to choose the right partners at the beginning and keep them involved by setting up a "win-win" situation with mutual benefits for all parties involved.

- Secure am inspirational leader that does not only start the $\mathrm{CC}$, but also has a community orientation and is able to build coalitions of partners around cluster's development.

- Secure diversity of likeminded people, involved in the cluster, in terms of professional affiliations and background; keep their belief in the collective impact and their motivation to contribute to the cluster.

- Create a "family feeling" and a safe internal environment before connecting with external partners.

- Balance the initial "startup passion" with the ability and competences to manage the creative cluster further; secure a CC leader that is also a good "connector".

19 Wemarket website: https://wemakeit.com/?locale=en

20 Ulej website: https://ulej.by/

21 Talaka website: https://www.talaka.org/projects/filter?type=3 


\section{LIDIA VARBANOVA}

- Put in place a governance structure that "regulates the freedom" and keep the passion in an organised way.

- Make the organisational structure of the CC fluid and open for constant change, do not over-structure.

- Organise mixed events in order to bring together companies and people from different sectors.

- Offer mixed programming combining traditional art forms with new media, digitalization, new technologies in order to attract young audiences and users.

- Keep all the time a collaborative mode in the $\mathrm{CC}$ as a lively place of sharing and interactions, and trust with the community.

- Keep an ongoing contact with local communities and engage them, make them feel the ownership on the CC by diverse entertainment, educational and other activities (e.f. restaurants, bars, parties, open stages, etc.)

- Increase the transparency via involving media in activities and results of the clusters-both conventional and social media.

The political will and the long-term commitment of initial funders, or investors, is of utmost importance for the success of a CC. Government authorities should recognise CCIs as an important area in the strategic cultural plans at national and local level. The understanding that CCs are part of development of creative industries, having also social goals, is of utmost importance for decreasing the fear of creatives that creative clusters can increase commercialization and decrease the public funding.

\section{BIBLIOGRAPHY:}

Bagwell, S. (2008) Creative Clusters and City Growth, in: Creative Industries, Journal Vol. 1, No 1.

Baltic Creative CIC: Annual report 2019: https://www.baltic-creative. $\mathrm{com} / \mathrm{wp}$-content/uploads/2019/11/baltic-creative-Master-version-forweb-compressed-2-10-year-Report-210-X-210-1.pdf

Balta, J. and Dragićević Šešić, M. (2017) Cultural rights and their contribution to sustainable development: implications for cultural policy, in: Intemational Joumal of Cultural Policy, Vol. 23, No. 2 issue, 2017, ISSN 1028-6632 DOI: 10.1080/10286632.2017.1280787

Bergman, E. and Feser, E. (1999) Industrial and Regional Clusters: Concepts and Comparative Applications, West Virginia University.

Boix, R., Lazzeretti, L., Hervas, J. L. and De Miguel, B. (2008) Creative clusters in Europe: A microdata approach, Ersa: 


\section{LIDIA VARBANOVA}

http://www-sre.wu.ac.at/ersa/ersaconfs/ersal 1/e110830aFinal00471 pdf

Branzanti, C. (2015) Creative clusters and district economies: Towards a taxonomy to interpret the phenomenon, European Planning Studies, 23(7).

Centre for Livable Cities, Singapore (2018) Urban System Studies. One North: Fostering Research, Innovation and Entrepreneurship; https://www.clc.gov.sg/docs/default-source/urban-systems-studies/ussone-north.pdf

Cooke, P. and Lazzeretti, L. (2008) Creative cities, cultural clusters and local economic development, Edward Elgar, Cheltenham.

Digital Creative Sectors in Coventry: Trends and Potential (2017) A report for Coventry Great Place, project by Stephen Roper (Warwick Business School), Areti Gkypali (Warwick Business School), Jane Sanderson (Coventry University) and Lorraine Morley (Morley Associates): Ltd)https://warwick.ac.uk/services/vco/exec/registrar/acb/ acb.04_digital_creative_industries_in_coventry.pdf

Dragićević Šsešić, M. Culture as a resource of a city development, in: Culturelink, special issue: The Creative City: Crossing Visions and New Realities in the Region, ed. Švob Đokic, N. (2006a), Zagreb, pp. 39-54; ISBN / ISSN: 978-953-6096-42-8.

Dragićević Šešić, M., Deru, J. P. and Simić Cultural diversitybased projects and their effects on sustainable development, in: The Sustainability of Cultural Diversity. Nations, Cities and Organizations, eds: Janssens, M., Bechtoldt, M., de Ruijter, A., Pinelli, D., Prarolo, G. and Stenius V. (2010), Edvard Elgar Publishers, Cheltenham; ISBN 9781849802895.

Dragićević Šešić, M., Rogač Mijatović, Lj. and Mihaljinac, N. (2017) Cultural Diplomacy: Arts, festivals and Geopolitics, Ministry of Culture Serbia and Faculty of Drama Arts, ISBN 978-86-8503334-6.

Evans, G. (2009) From Cultural Quarters to Creative ClustersCreative spaces in the new city economy, Stockholm: Institute of Urban History: https://bura.brunel.ac.uk/bitstream/2438/6475/2/ Cultural $\% 20$ quarters $\% 20 \& \% 20$ urban $\% 20$ regeneration-evans.pdf

Florida, R. and Mellander, C. (2008) Music Clusters: A Preliminary Analysis, The Martin Prosperity Institute.

Gordon, I. R. and McCann, P. (2000) Industrial clusters: Complexes, agglomeration and/or social networks? Urban Studies, 37(3), pp. 513-532; https://doi.org/10.1080/0042098002096.

Glowacki, M. and Jackson, L. (2019) Organizational Culture of Public Service Media: People, Values, Processes: (https://www. creativemediaclusters.com/images/Glowacki_Jackson_2019.pdf

Hristova, S., Dragićević Šešić, M. and Duxbury, N. eds. (2015) Cultural Sustainability in European Cities: Imagining Europolis (Routledge Studies in Culture and Sustainable 


\section{LIDIA VARBANOVA}

Development), Routledge; ISBN-10: 1138778419, ISBN-13: 9781138778412 .

Jong, de V. (2012) Nodes of Creativity. Unlocking the Potential of Creative SMEs by Managing the Soft Infrastructure of Creative Clusters, Erazmus University Rotterdam.

Kind, S. and Meier zu Köcker, G. (2012) Developing Successful Creative \& Cultural Clusters. Measuring their outcomes and impacts with new framework tools, Berlin: Projectzukunft. Komorowski, M. (2017a) A novel typology of media clusters, European Planning Studies, 25(8); https://doi.org/10.1080/09654313.2017.1303823.

Komorowski, M. and Picone, I. (2020) Creative Chuster Development. Governance, Place-making and Entrepreneurship, Routledge.

Landry, C. (2008) The creative city: A toolkit for urban innovators, London: Earthscan.

Lazzeretti, L., Capone, F. and Boix, R. (2012) Reasons for clustering of creative industries in Italy and Spain, European Planning Studies, 20(8).

Machado, A. F., Simões, R. F. and Diniz, S. C. (2013) Urban amenities and the development of creative clusters: The case of Brazil, Current Urban Studies, 1(4), pp. 92-101.

Ministry of Tourism and Culture, Ontario (2010) Ontario's Entertainment and Creative Cluster. A Framework for Growth; http:// www.mtc.gov.on.ca/en/publications/Creative_Cluster_Report.pdf

NESTA (2010) Creative Clusters and Innovation. Putting Creativity on the Map; https://media.nesta.org.uk/documents/creative_clusters_and_ innovation.pdf

NESTA, Hivos, British Council: Creative Hub Leader's Toolkit; https://creativeconomy.britishcouncil.org/media/resources/Creative_ Hub_Leaders_Toolkit.pdf

Nielsén, T. and Power, D. (2011) Priority sector report: Creative and cultural industries. Retrieved from Publications Office of the European Union website: http://ec.europa.eu/DocsRoom/ documents/615/attachments/1/translations/en/renditions/pdf .

Porter, M. J. (1998) Clusters and the new economics of competition, Harvard Business Review, November-December.

Pratt, A. (2004) Creative clusters: towards the governance of the creative industries production system?, Media International Australia incorporating Culture and Policy, pp. 50-66.

Sandel, T. and Skarveli, L. (2016) Mapping exercise: How could creative industries foster innovation in tourism in the northern dimension area? Country Report-Lithuania, funded by the European Union.

Schools Excellent Fund - Creative Clusters, Ireland: https://www. education.ie/en/Schools-Colleges/Information/Curriculum-andSyllabus/cap_creative_cluster_guidelines.pdf 


\section{LIDIA VARBANOVA}

Skavronska, I. (2019) Creative Clusters and the Position of Ukraine in the Market of Creative Products. Research Paper, UNICTAD: https:// unctad.org/meetings/en/Contribution/cep2019-22-10-contribution_en_ Ukraine.pdf

V4 Creative Incubators: Guide to Places and Spaces of Creative Incubators in Central Europe, ed. Zora J. (2015) Budobs, Budapest; http://www.budobs.org/files/v4_creative_incubators.pdf

Wu, W. (2005) Dynamic Cities and Creative Clusters, Policy Research Working Paper No. 3509. World Bank, Washington, DC: https:// openknowledge.worldbank.org/handle/10986/8863

Zenna, C. (2019) The Anatomy of a Creative Cluster. Inspiration from Global Creative Initiatives.

\section{Online Resources:}

11 Inspirational Co-working Spaces: https://www.creativebloq.com/ inspiration/11-inspirational-co-working-spaces-to-make-you-morecreative

30 Munster Schools are Part of Creative Cluster (September, 2018): https://www.irishexaminer.com/breakingnews/ireland/30-munsterschools-are-part-of-creative-cluster-871151.html

Accelerators and incubators- https://www.sbir.gov/node/822177

Accelerators versus incubators - What startups need to know (June 2018) https://www.techrepublic.com/article/accelerators-vsincubators-what-startups-need-to-know/

Bangkock Creative District will Inspire you to Dream Bigger (February, 2019): https://www.advocate.com/travel/2019/2/05/onenight-bangkok-exposes-citys-little-known-gems

Clusters are at the Heart of the Creative Economy, Charles Armstrong: https://creativeconomy.britishcouncil.org/guide/clusters-are-heartcreative-economy/

Co-working Spaces for Artists and Creatives (December, 2018): https://www.coworkingresources.org/blog/coworking-spaces-forartists-and-creatives

Creation and Implementation of Cluster Model of Folk Artistic Crafts Development, Ukraine: http://personal.pu.if.ua/depart/svitlana. kropelnytska/resource/file/Investment_project_Suzirya.pdf

Creative Clusters Lead to Creative Communities (May, 2011): https://www.huffpost.com/entry/creative-clusters-leadto_b_844074?guccounter=1\&guce_referrer=aHR0cHM6Ly93 d3cuZ2 9vZ2xlLmNvbS8\&guce_referrer_sig=AQAAAB9xFH-pptgXMYyP0 6jkPY6JdIHIlsovyMuckrrB1JBMaxJuavWNr z6RZz6OvDaCeSGTM bDRLjAi2uNb9q4ZxGzvWHG6MAjZmvnwNH8SdViB1Ztp05wR6xv Pj--9c7skTp5h7CGP94y2bsehhWD85X57dU3WsWDMALHt7zd8ctZ

Creative Hubs, British Council: https://creativeconomy.britishcouncil. org/projects/hubs/ 


\section{LIDIA VARBANOVA}

Creative Industries Cluster Programme, UK: https://clwstwr.org.uk/ about/creative-industries-clusters-programme

Establishment and Development of Arts Incubators, UNESCO Diversity of Cultural Expressions: https://en.unesco.org/creativity/ policy-monitoring-platform/establishment-development-art

How Creative Clusters Spur Innovation (September 2016): (https:// www.livemint.com/Companies/o2NfSYxi5cxV2NyyNr95gK/Howcreative-clusters-spur-innovation.html

Hubs, Clusters and Regions, John Newbegin: https://creativeconomy. britishcouncil.org/guide/hubs-clusters-and-regions/

Luxembourg Creative Industries Cluster: https://www.luxinnovation. lu/cluster/luxembourg-creative-industries-cluster/

NESTA Names Eastbourne as a Creative Cluster (August, 2018): https://techresorteb.com/nesta-names-eastbourne-as-a-creative-cluster/

One-north: A Vibrant Centre of Innovation (May 2019): https://www. channelnewsasia.com/news/advertorial/one-north-a-vibrant-centre-ofinnovation-11510004

Ontario Investments Driving Innovations and Creative Cluster Growth (February, 2017): (http://www.mtc.gov.on.ca/en/creative_cluster/ cluster_report_driving_innovation.shtml

Plovdiv's Kapana Creative District: From Decay to Art Hub: https:// theculturetrip.com/europe/bulgaria/articles/plovdivs-kapana-creativedistrict-from-decay-to-art-hub/

South Africa Should Turn to "Creative Clusters" to Boost the Arts: (May 2018): https://theconversation.com/south-africa-should-turn-tocreative-clusters-to-boost-the-arts-96294

Startup accelerators-virtual programs (April, 2020): https:// venturebeat.com/2020/04/01/startup-accelerators-forge-ahead-withnew-virtual-programs/

Woodstock Design District: 5 creative businesses to know (November, 2019): http://wid.co.za/blog/woodstock-design-district-5-creativebusinesses-to-know/

The key role of business incubators and accelerators in Latin America - https://www.ada-microfinance.org/en/covid-19-crisis/fiche-covid-19crisis/2020/05/key-role-incubators-accelerators-latin-america

Volkstrant Buliding Research (December, 2014): https://www. volkshotel.nl/en/blog/art-cult/volkskrant-building-research/

\section{Websites of Clusters}

Bangkok Creative District, Thailand: https://creativedistrictbangkok. $\mathrm{com} /$

Beirut Creative Cluster, Lebanon: http://beirutcreativecluster.org/

Creative Cardiff: https://www.creativecardiff.org.uk/ 


\section{LIDIA VARBANOVA}

Creativehubs network: http://creativehubs.net/

Creative Industry Cluster, Hungary: https://www.kreativipariklaszter. $\mathrm{hu} /$ (only in Hungarian language).

Creative Industries Cluster Vojvodina - https://www.kvik.rs/home (in Serbian language).

Creative Industries Cluster, UK: https://creativeindustriesclusters.com/

Creative Cluster Kombinat, Rijeka, Croatia: https://kombinat.hr/

CRU Cowork, Porto, Portugal: https://cru-cowork.com

FutureLab website: https://futurelab-eindhoven.nl/ (Only in Dutch language).

GoDown Arts Centre, Kenya: https://www.thegodownartscentre.com/

ICT, Media and Creative Industries Cluster, Berlin-Brandenburgh https://health.clust-er.it/en

IDM Suedtirol - https://www.idm-suedtirol.com/

Impact HUB, Prague, Czech Republic: https://www.hubpraha.cz/en

Kapana Creative District, Plovdiv, Bulgaria: https://visitkapana.bg/en

Luxembourg Creative Industries Cluster: https://creativecluster.lu/

MOB Barcelona: https://mob-barcelona.com/

MTNS MADE Creative Industries Cluster, Australia: https:// mtnsmade.com.au/

One North Cluster, Singapore: https://en.wikipedia.org/wiki/One-north Open Hub Cr, Czech Republic: http://prague. the-hub.net

Transylvania Creative Industries Cluster, Romania: http:// creativetransilvania.ro/en/

Zlin Creative Cluster: http://kreativnizlin.cz/en/

\section{List of Interviewes:}

Dr. Dane Anderson, Senior Lecturer in Strategy, Innovation and Entrepreneurship, Director of Programmes in Executive Education, University of Manchester, Manchester, UK.

Koen Snoecx, Collision expert \& -maker at www.luscinus.be, Belgium.

Dr Marlen Komorowski, Researcher, consultant and lecturer with a focus on creative cluster research, senior researcher at imecSMIT-VUB and impact analyst at Clwstwr, a programme at Cardiff University, UK/Belgium/Germany.

Dr. Michal Glowacki, Lecturer and researcher, Faculty of Journalism, Information and Book Studies, University of Warsaw, Poland.

Mies Loogman, Designer \& Creative Strategist, Chairwoman Association Sectie-C, Eindhoven, The Netherlands. 


\section{LIDIA VARBANOVA}

Dr. Pawan V. Bhansing; Independent researcher and consultant on dual leadership, creative business centres, and organizational values, The Netherlands.

Petr Vitek, Co-founder at Impact Hub \& Tilia Impact Ventures; Member of the Board at Ceská spořitelna Foundation, Prague, Czech Republic.

Svitlana Kropelnytska, Assoc.Prof., Department of Finance, Project and Educational Center "Agents of Changes", Vasyl Stefanyk Precarpathian National University, Ukraine.

Tania Santos, Founder/<amaher, CRU Cowork, Porto, Portugal.

Tatjana Kalezic, Independent Expert for Innovation and Creative Business Development, Founder of the Creative Industries Cluster of Vojvodina, Managing Director of the Serbia Start Up Association: Novi Sad, Serbia.

Dr. Yosha Wijngaarden, postdoctoral researcher, dept. Arts and Culture Studies, Erasmus School of History, Culture and Communication, Erasmus University Rotterdam, The Netherlands.
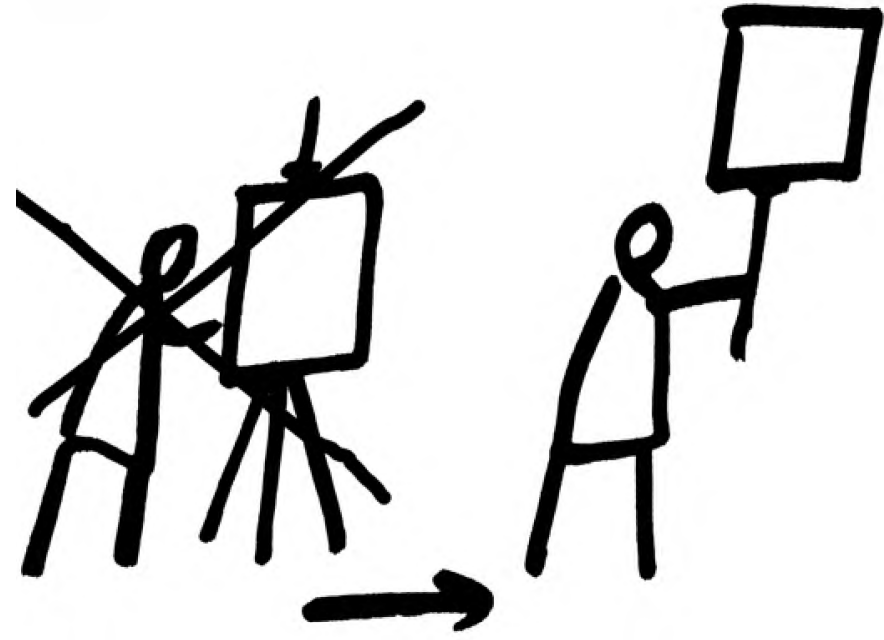

Dan Perjovschi, Artist today, marker on paper, 2008 , courtesy the artist 


\title{
LIDIA VARBANOVA
}

\section{Лидија Варбанова}

Национална академија за позоришне и филмске студије, Софија, Бугарска

\section{КРЕАТИВНИ КЛАСТЕРИ}

\author{
ТИПОЛОГИЈА, ОДЛИКЕ, ФННАНСНЈСКИ МОДЕЛИ И \\ ФАКТОРИ УСПЕХА
}

\section{Сажетак}

Глобална пандемија мења свет веома великом брзином и у многим сферама - привредној, друштвеној, културној, дигиталној. Ковид-19 је несумњиво негативно утицао на све секторе који захтевају путовања и физичко присуство, укључујући ту многе уметничке и културне догађаје и организације, као и секторе који су комплементарни вредносном ланцу културе и креативннх индустрија. Упркос томе, глобална пандемија отворила је и неке нове могућности за живот ближи заједници, већу потрошњу локалних производа, реорганизацију живота тако да буде отпорнији на промене, катализаццју како пословних тако и друштвених иновација, веће коришћење дигиталних и мрежних алата, укључујући ту и додатно повећање културне партиципације и демократизације уметности. У последьих неколико месеци сведоци смо великог броја доказа да култура заиста доприноси привредној и друштвеној виталности градова широм света. Циљ овог рада је да идентификује суштину и кључне одлике „креативних кластера" и да понуди типологију разних форми у којима они постоје. Такође, рад сумира кључне пословне моделе и изворе екстерне финансијске подршке развоју ових кластера. Најзад, у раду се изводи закључак о кључним факторима успеха у њиховом развоју. Истраживања за потребе овог рада вршена су у тромосечју април-јун 2020, у сарадњи са Николозом Надираппвилијем и Креативном Грузијом, у оквиру пројекта - „Осмишљавање екосистема Креативног кластера Грузије” под покровитељством УНЕСКА и Европског савета. Истраживачке методе коришћене у припреми овог рада су: канцеларијско истраживање документације и публикација, мапирање и анализа различитих случајева и циљаних дубинских интервјуа са професноналцима и менаџерима који воде креативне кластере.

Кључне речи: креативни кластери, креативни центри, креативни региони, урбана регенерација воһена културам 